\title{
The Application of Hierarchical Teaching Method in College Football Selective Course
}

\author{
Wei Xu \\ College of Technology and Art Jingdezhen Ceramic Institute \\ Jingdezhen, Jiangxi, China, 333001
}

\begin{abstract}
Hierarchical teaching is a process that completes the individualization of students' learning and the synchronization of teachers' guidance and makes teaching become an efficient and unified process for teaching and learning activities. In the course of this research, students from the Jingdezhen Ceramic Institute were taken as a case study. The control group and the experimental group were set up to carry out general teaching and hierarchical teaching, and changes in physical fitness, special skills and learning interests of the two groups of students were analyzed. This work deeply explored the matters needing attention in the application of hierarchical teaching methods in college football selective courses, and it is expected to offer a certain reference for college football teaching.
\end{abstract}

Keywords-College football; Hierarchical teaching; Teaching method; Teaching effect

\section{INTRODUCTION}

The physical education curriculum in China is closely centered on the training of students' physical exercise methods and the improvement of students' physical fitness. College physical education is of great significance. Many excellent talents have great advantages in learning professional knowledge since they have entered the college through testoriented education in the middle school stage [1-2]. On the contrary, students feel at a loss when the physical courses that are not valued in the middle school stage enter the college.

The development of Jiangxi football has a long history, and the level of development is lower than that of domestic coastal areas and developing provinces. Particularly, the development of football in Jiangxi regular colleges is not very good. Through the investigation and analysis of the current situation of Jiangxi football, this work found that the teaching method of the football selective course in regular colleges of Jiangxi still adopts the traditional teaching mode and ideological concept. Teacher does not have a full understanding of students' interest and individual differences but adopt a uniform teaching method, which results in students' low interest in learning [3]. Therefore, this work applied a hierarchical cooperative teaching method to college football selection course in Jiangxi in order to improve the current situation of students' learning. Certainly, in the teaching process, it is necessary to explore some better teaching methods to improve students' enthusiasm for learning, so as to firmly establish the concept of lifelong sports [4-5]. As far as the current situation is concerned, college physical education teachers have discussed the application of single teaching method, and they fully understand the advantages and disadvantages of this teaching method, but they cannot fully utilize the mixed-use of multiple teaching methods. Therefore, this work tried to compare the traditional teaching methods with the hierarchical cooperative teaching method in college football selective course in Jiangxi and summarized a set of more perfect hierarchical cooperative teaching method based on advantages of both the hierarchical cooperative teaching method and the traditional teaching method, so as to provide necessary reference for the teaching reform of the college football selective course in Jiangxi.

\section{ReseARCh OBJective AND Methodology}

\section{A. Research objective}

Jingdezhen Ceramic Institute is a key undergraduate art school in Jiangxi Province, which mainly features ceramics. This work selected 100 students who entered the university in 2018 as the research object and conducted a placement test before the hierarchical teaching experiment. The test content includes basic body indicators (height, weight, and age), sports quality indicators $(5 * 25$ meters out-and-back, 1500 meters running and in-situ shot put), and football technical level (juggling, 25 meters positional kicking and dribbling).

After the test, all 100 students should be divided into an experimental group and a control group according to the test data, and $\mathrm{P}$ is greater than 0.05 , which means that there is no significant difference between the two groups. The experimental group should be divided into an improvement class (22 people) and elementary class (28 people) according to the level of students, in contrast, the control group should be randomly distributed evenly, and students in the class have significant difference.

\section{B. Research methodology}

\section{1) Teaching experiment method}

This method is to test the practical effect of "hierarchical teaching method" through teaching. The control group adopts the traditional football teaching method, and the experimental group adopts the hierarchical teaching method, which divided students into three levels according to their levels of football. Before and after the semester, the university should test students' physical quality and football skill level in accordance with relevant standards, and analyze the results statistically.

Experimental time: September to December 2018, a total of 36 hours. 
Experimental Location: Football stadium in Jingdezhen Ceramic Institute

\section{Experiment procedure:}

(1) Object hierarchy. In the teaching process, the goal is the main part and the content is the subordinate part, so it is necessary to drive other links by grasping the key. In the hierarchical teaching experiment, the experimental group has two different levels of teaching classes, and students' abilities are different. Therefore, separate teaching objectives must be set for each level, as shown in Table 1.

TABLE I. DESIGN OF HIERARCHICAL TEACHING OBJECTIVES IN THE EXPERIMENTAL GROUP

\begin{tabular}{|l|l|}
\hline Level & Teaching objectives at all levels \\
\hline Improvement & $\begin{array}{l}\text { Fully master the content stipulated in the syllabus, skillfully } \\
\text { use various football skills, understand football rules, and use } \\
\text { them in general football games }\end{array}$ \\
\hline Elementary & $\begin{array}{l}\text { Basically, master the content stipulated in the syllabus can } \\
\text { use most of the required football skills, probably know the } \\
\text { football rules, and improve the interest in football outside the } \\
\text { classroom. }\end{array}$ \\
\hline
\end{tabular}

(2) Teaching content. Students in the elementary class often do not have a football foundation or a poor foundation. Therefore, class teaching should be arranged in strict accordance with the syllabus and lay down the basic skills in a down-to-earth manner. Under the premise of satisfying the scholastic ability of most students, some students who have spare energy should be offered some higher requirements. In addition, the teaching focus of students in the improvement class should be on requiring higher requirements, so as to help them use the technical actions learned in the classroom freely in actual combat, achieving the effect of integration, for example, adding some content of tactical knowledge appropriately can help students' better use the effect of technical movements

(3) Teaching method. The elementary class adopts a teaching method that cans solid foundation and has clear targets, so as to help students make progress step by step. It should follow the principle of "slowing the progress, repeating over and over again, paying attention to three basics, and giving feedback frequently" to create opportunities for students to have a sense of accomplishment. It should also use model teaching, which can encourage students to practice techniques and improve themselves. Instead, improvement class uses inspiration and guidance-based teaching methods. Teachers should focus on explaining and demonstrating the main links of technical teaching and encourage students to think deeply through self-thinking and practice. After learning the intuitive feelings of technical movements, students should deeply think about principles and communicate with students and teachers. Only in this way can they check and fill the gap, strive for excellence, and thoroughly understand the overall structure of technology.

\section{2) Mathematical statistics method}

SPSS 11.0, EXCEL and other software should be used for statistical analysis and processing of data to verify the practical effect of the hierarchical teaching method.

\section{RESULTS AND DISCUSSION}

\section{A. Physical condition}

After a whole semester of being taught by traditional methods, students in the control group were carefully observed. The results of the shot-put project were not obvious, and the improvement of the $5 * 25$ meters out-and-back and the 1500 meters run was more obvious. It can be seen that the traditional teaching method has a certain effect. By comparison, for students in the experimental group, there was little change in students' performance of the shot-put project, and the $5 * 25$ meters out-and-back and the 1500 meters run had substantial achievement improvement. The difference before and after the teaching experiment is obvious, so it can be seen that the teaching experiment has a significant effect on the physical quality improvement of the experimental group students, as shown in Table II.

TABLE II. STUDENTS PHYSICAL FITNESS TEST DATA

\begin{tabular}{|c|c|c|c|c|}
\hline Group & Test content & Before the test & After the test & $\mathrm{P}$ \\
\hline \multirow{3}{*}{ Control group } & $5 * 25$ meters out-and-back(second) & $34^{\prime \prime} 9$ & $32 " 7$ & $>0.05$ \\
\hline & Shot put (meter) & 10.9 & 11.2 & $>0.05$ \\
\hline & 1500 (meter) & $5^{\prime} 39^{\prime \prime}$ & $5^{\prime} 26^{\prime \prime}$ & $>0.05$ \\
\hline \multirow{3}{*}{$\begin{array}{l}\text { Experimental } \\
\text { group }\end{array}$} & $5 * 25$ meters out-and-back(second) & $35^{\prime \prime} 6$ & $32^{\prime \prime 2}$ & $>0.05$ \\
\hline & Shot put (meter) & 11.6 & 11.9 & $>0.05$ \\
\hline & 1500 (meter) & $5^{\prime} 43^{\prime \prime}$ & $51^{\prime \prime}$ & $>0.05$ \\
\hline
\end{tabular}

According to the difference of test results before and after the test, it can be seen that after the completion of the teaching, the students in the experimental group have a more obvious improvement in physical fitness performance than the students in the control group.

\section{B. Special technical achievements}

After a whole semester of being taught by traditional methods, students in the control group are carefully observed. The result changes of the dribbling are not obvious, and the results of the juggling and 25 meters positional kicking are improved. It can be seen that the traditional teaching method has a certain effect on the improvement of students' special skills. By comparison, for students in the experimental group, the results of the three special technical tests are greatly improved, and there is a significant difference compared with the control group. Therefore, the hierarchical teaching method has a better effect on the improvement of students' special technical skills, as shown in Table III. 
TABLE III. STUDENT SPECIAL TECHNICAL TEST DATA

\begin{tabular}{|c|c|c|c|c|}
\hline Group & Test content & $\begin{array}{c}\text { Before } \\
\text { the test }\end{array}$ & $\begin{array}{c}\text { After the } \\
\text { test }\end{array}$ & $\mathrm{P}$ \\
\hline \multirow{4}{*}{ Control group } & Dribbling (second) & $11^{\prime \prime 2} 21$ & $11^{\prime \prime} 07$ & $>0.05$ \\
\cline { 2 - 5 } & Juggling (pcs) & 4 & 14 & $<0.05$ \\
\cline { 2 - 5 } & $\begin{array}{c}\text { Meter kicking } \\
\text { (minute) }\end{array}$ & 76 & 80 & $<0.05$ \\
\hline \multirow{3}{*}{$\begin{array}{c}\text { Experimental } \\
\text { group }\end{array}$} & Dribbling (second) & $11^{\prime \prime} 67$ & $10^{\prime \prime} 37$ & $<0.05$ \\
\cline { 2 - 5 } & Juggling (pcs) & 3 & 16 & $<0.05$ \\
\cline { 2 - 5 } & $\begin{array}{c}\text { Meter kicking } \\
\text { (minute) }\end{array}$ & 74 & 87 & $<0.05$ \\
\hline
\end{tabular}

According to the different test table between the control group and the experimental group, although the performance of the juggling and 25 meters positional kicking for both groups has improved, the improvement of the experimental group is significantly larger. In addition, there was not much improvement of students in the control group in terms of dribbling, but the students in the experimental group made great progress. The above results show that the hierarchical teaching method is obviously superior to the traditional teaching method in the teaching effect of football special technical ability.

\section{Active participation}

According to the survey results, students in the experimental group who received the "hierarchical teaching method" were significantly more active in the extracurricular activities than students in the control group. Their amount of time and frequency of extracurricular exercise were more than that of the control group, the number of students who paid attention to football matches was more, and they participated in various football matches and activities in daily life more actively. This fully demonstrates that the "hierarchical teaching method" implemented in college football lessons can stimulate students' interest in learning football. It not only mobilizes students' enthusiasm for learning in the classroom, but also encourages students to participate more actively in football activities outside the classroom. In the control group, the "hierarchical teaching method" has a more positive significance in comprehensively enhancing students' participation in exercise awareness, as shown in Table IV.

TABLE IV. STUDENT ENGAGEMENT DATA

\begin{tabular}{|c|c|c|c|c|c|}
\hline \multirow[b]{2}{*}{ Test content } & \multirow[b]{2}{*}{ Option } & \multicolumn{2}{|c|}{ Experimental group } & \multicolumn{2}{|c|}{ Control group } \\
\hline & & $\begin{array}{l}\text { Number of } \\
\text { people }\end{array}$ & Percentage \% & $\begin{array}{l}\text { Number of } \\
\text { people }\end{array}$ & $\begin{array}{l}\text { Percentage } \\
\%\end{array}$ \\
\hline \multirow{3}{*}{$\begin{array}{l}\text { Do you participate in football activities outside the } \\
\text { classroom? }\end{array}$} & A Often & 40 & 80 & 28 & 56 \\
\hline & B Occasionally & 8 & 16 & 19 & 38 \\
\hline & C Never & 2 & 4 & 3 & 6 \\
\hline \multirow{3}{*}{ How many times a week do you play football? } & A 4-6 times & 25 & 50 & 17 & 34 \\
\hline & B 2-3 times & 22 & 44 & 26 & 52 \\
\hline & C 1time and below & 3 & 6 & 7 & 14 \\
\hline \multirow{3}{*}{ How long does it take to participate in football every time? } & A More than 30 minutes & 46 & 92 & 41 & 82 \\
\hline & B 15-30 minutes & 4 & 8 & 7 & 14 \\
\hline & C Not involved & 0 & 0 & 2 & 4 \\
\hline \multirow{3}{*}{$\begin{array}{l}\text { Are you actively participating in the school football } \\
\text { competition? }\end{array}$} & A Participation & 35 & 70 & 20 & 40 \\
\hline & $\begin{array}{l}\text { B Interested but not } \\
\text { involved }\end{array}$ & 10 & 30 & 14 & 28 \\
\hline & C Not involved & 5 & 10 & 16 & 32 \\
\hline \multirow{3}{*}{ Do you usually pay attention to football matches? } & A Pay great attention & 41 & 82 & 33 & 66 \\
\hline & B Occasionally concerned & 8 & 16 & 14 & 28 \\
\hline & C Never pay attention & 1 & 2 & 3 & 6 \\
\hline
\end{tabular}

\section{Teaching implementation situation}

According to the results, students in the experimental group are more satisfied with the classroom teaching than the control group students after one semester of teaching experiments. They have higher learning enthusiasm and initiative in class, and they can achieve teaching goals more actively in class. Besides, they think their skills have been improved, which indicates a stronger sense of achievement in study. After completing the teaching, students in the experimental group also love football more than the students in the control group. There is little difference between the two teaching methods in dealing with the teacher relationship. In the teaching situation, the hierarchical teaching effect is obviously better than ordinary teaching, and its specific situation is shown in Table 5.

TABLE V. TEACHING SITUATION SURVEY

\begin{tabular}{|c|c|c|c|c|c|c|}
\hline \multirow{2}{*}{ Survey content } & \multicolumn{3}{|c|}{ Experimental group } & \multicolumn{3}{|c|}{ Control group } \\
\hline & Sure & Neutral & Deny & Sure & Neutral & Deny \\
\hline 1. Does the classroom teaching method apply to you & 32 & 11 & 7 & 26 & 18 & 6 \\
\hline 2, Have you mastered the content of the class & 36 & 12 & 2 & 21 & 23 & 5 \\
\hline $\begin{array}{l}\text { 3. Whether the wrong action in the learning can be } \\
\text { corrected in time }\end{array}$ & 29 & 15 & 6 & 28 & 16 & 6 \\
\hline 4. Can you actively learn & 35 & 10 & 5 & 24 & 10 & 16 \\
\hline $\begin{array}{l}\text { 5. After the football lesson, do you think your } \\
\text { football level is improved }\end{array}$ & 37 & 10 & 3 & 19 & 19 & 12 \\
\hline 6. Do you prefer football more after the football class & 29 & 16 & 5 & 18 & 20 & 12 \\
\hline $\begin{array}{l}\text { 7. Are you satisfied with the teacher's classroom } \\
\text { teaching }\end{array}$ & 41 & 5 & 4 & 17 & 26 & 7 \\
\hline 8. Are you in harmony with the teacher? & 43 & 6 & 1 & 41 & 7 & 2 \\
\hline
\end{tabular}




\section{E. Teaching satisfaction situation}

According to questionnaires, it can be found that after the completion of the teaching experiment, students in the experimental group generally have a stronger interest in football. The number of students who are "very interested" in football increases from 18 to 27, and the number of students who are "not interest" in football decreases from 6 to 1. In contrast to the control group, the traditional teaching method does not improve the students' enthusiasm in football. The number of people who are "very interested" in football remains unchanged at 18, but the number of students who are "not interested" in football increases to nine. This shows that the traditional teaching method is boring and monotonous, and students are no longer interested. The hierarchical teaching method can motivate students' enthusiasm for learning and achieve the purpose of stimulating students to participate in football through football classes.

In terms of teaching satisfaction, 24 students in the experimental group feel "very satisfied" with the classroom teaching method, accounting for $48 \%$ of the total number of experimental groups; the number of students who feel "satisfied" is 15 , accounting for $30 \%$ of the total number of experimental groups; the number of students who feel "generally satisfied" is 7 , accounting for $14 \%$ of the total number of experimental groups; the number of students who feel "dissatisfied" is 4 , accounting for $8 \%$ of the total number. It can be seen that from the perspective of the students' intuitive feelings, they are generally satisfied with the hierarchical teaching mode, and they are willing to accept it psychologically.

\section{SUMMARY AND RECOMMENDATIONS}

\section{A. Summary}

(1) The hierarchical teaching conforms to the requirements of quality education and has more advantages than the traditional teaching methods. It can better implement the principle of "teaching students in accordance with their aptitude" and meet the needs of students with different learning bases.

(2) The hierarchical teaching can stimulate the students' learning motivation through the incentive mechanism, which is convenient for teachers to arrange the teaching content more reasonably. Through hierarchical teaching, scientific and standardized teaching management has been promoted. The teaching objectives are more suitable for different students at different levels. The content taught by teachers is more targeted, and the amount of homework is appropriate for students with different characteristics. At the same time, the evaluation system of students is improved to make the evaluation of students and teachers more scientific and objective, which is conducive to mobilizing students' learning enthusiasm.

(3) The hierarchical teaching method avoids the drawbacks of rigid and monotonous traditional teaching method, and can stimulate students' enthusiasm for learning football in teaching so that students can experience the fun of football and feel the sense of accomplishment of improving football skills. They not only study hard in the classroom, but also get interested in football outside of class. Many students in the experimental group make changes from the previous time when they did not pay attention to football matches to the end of the teaching when they will take the initiative to pay attention to football matches and participate in after-school football matches on and off-campus, and they develop a good habit of regular exercise and fitness.

(4) The hierarchical teaching is conducive to the healthy development of students' psychology. In teaching, it is found that the learning ability of the experimental group students is significantly stronger than that of the control group students. Students' basic football skills have been greatly improved, enhancing the interest and enthusiasm of college students to learn football.

\section{B. Recommendations}

(1) Strengthening the construction of professional teams. It is necessary to improve the teaching knowledge and teaching ability of teachers, and to cultivate the professional quality of teachers in accordance with the requirements of footbal teaching in colleges and universities in China, so that they can complete various teaching tasks with high quality and high efficiency. Especially in the application of hierarchical teaching methods, it is necessary to conduct a comprehensive analysis of the hierarchical teaching concept, content and innovation path to ensure that it can be fully used in college football teaching [6]. In the application of hierarchical teaching, teachers should have a high level of teaching, and be familiar with the content of the subject, a variety of different teaching methods and the students in each class, so that they can be more comfortable to apply the hierarchical teaching method in daily teaching [7]. Therefore, teachers are required to spend a certain amount of time and energy before the class carefully studying the teaching materials, and extensively understanding the situation of the students in order to teach students in accordance with their aptitude.

(2) Completing the hierarchy of teaching content. Whether the hierarchy of teaching content is reasonable is related to whether it can meet the learning needs of students at different levels, whether it can mobilize students' interest, and whether the teaching objectives can be achieved smoothly. In order to lay the foundation for the smooth implementation of the hierarchical teaching method, college football teaching should pay attention to the hierarchy of teaching content [8]. For advanced level students, the teaching content should be focused on the further explanation and training of football skills, so as to improve students' flexible use of various skills and pay attention to the cultivation of good study habits. For intermediate level students, the teaching should do a good job of explaining the basic knowledge of football to further consolidate the basic knowledge of football [9-10]. At the same time, teachers should understand the situation of students' football skills, and carry out targeted training, so that students can master relevant skills. For lower-level students, teachers should focus on basic knowledge teaching, explain the rules of football in detail for students, and make them have a comprehensive understanding of football. In the teaching of college football, the hierarchy of teaching content can not only 
meet the learning needs of different level students, but also avoid hurting the enthusiasm of students to learn, which can help students establish their self-confidence in learning football knowledge.

(3) Forming a hierarchy of scientific assessment. In football teaching, an assessment is required to understand students' knowledge of football. However, if the content of the assessment is not set up properly, there will be a big gap in students' assessment results, which may easily cause some students' emotional loss, dampen students' enthusiasm in learning to some extent, and hinder the smooth development of football teaching activities. Therefore, in college football teaching, the assessment content should be hierarchical. According to the improved situation of students' physical quality and the mastery situation of football knowledge, the content of assessment should be reasonably set [11]. For example, the key points of the advanced level students assessment include whether the physical quality is further improved, whether the skills and application of football skills are proficient, whether the tactics of learning can be used flexibly, and whether the cooperation with the team members is reasonable; the key points of the lower- level students assessment include whether the physical quality is significantly improved, whether the basic knowledge of football is firmly grasped, and whether some common skills are known.

(4) Ensuring that teaching science is applicable. Under the current situation that China's educational resources and teachers are still relatively scarce, it may not be realistic to promote the hierarchical teaching method on a large scale. It can be applied in some regions and schools where education resources are rich and the quality of education is better. In the above-mentioned regional teaching, special attention should be paid to avoiding students' frustrated psychology and negative attitudes, creating a positive and virtuous competitive atmosphere, exploring students' interest in football, and encouraging students to participate in football activities outside the classroom. It is necessary to pay attention to rethinking and summarizing in teaching, and to explore various teaching methods including hierarchical teaching methods, so as to constantly innovate teaching methods and improve teaching effects.

\section{REFERENCES}

[1] Qiu, F., \& Zhou, Y. Practical Application of Creative Education in College Football Teaching. Informatics and Management Science III. Springer London. (2013)

[2] Zhang, R., \& Wang, Y. The Application of Task-Driven Teaching Method. International Conference on Information Technology. IEEE. (2011)

[3] Wu, J. Experimental research on application of mutual-aid teaching method in technique teaching of university's football elective course.

[4] Wenzhi, J., \& Education, D. P. Objective quantification and hierarchical teaching of football course in general colleges and universities. Journal of University of Science and Technology Liaoning. (2013).

[5] Gong, H., Liang, P., Jin, Y., Xu, S., \& Zhang, Y. The hierarchical teaching method exploration for curriculum design of photoelectric discipline. 14th Conference on Education and Training in Optics and Photonics, ETOP 2017. (2017)

[6] Gould, D., Collins, K., Lauer, L., \& Chung, Y. Coaching life skills through football: a study of award-winning high school coaches. Journal of Applied Sport Psychology, 19(1), 16-37. (2007)

[7] Zhou, J., O'Brien, K. S., \& Heim, D. Alcohol consumption in sportspeople: the role of social cohesion, identity and happiness. International Review for the Sociology of Sport, 49(3-4), 278-293. (2013)

[8] Lykken, D. T., Bouchard, T. J. J., Mcgue, M., \& Tellegen, A. Emergenesis: genetic traits that may not run in families. American Psychologist, 47(12), 1565-77. (1992)

[9] Pill, \& Shane Teaching Australian football in physical education: constraints theory in practice. Strategies, 26(1), 39-44. (2013)

[10] Duda, H. Cognitive support in teaching football techniques. Biomedical Human Kinetics, 1. (2009)

[11] Turman, P. D. Coaches' immediacy behaviors as predictors of athletes' perceptions of satisfaction and team cohesion. Western Journal of Communication, 72(2), 162-179. (2008) 